\title{
PENGARUH KEPEMIMPINAN KONSIDERASI, DISIPLIN KERJA DAN ORIENTASI KERJA TERHADAP KINERJA PEGAWAI MELALUI MOTIVASI BERPRESTASI (Studi Kasus Pada PNS Kecamatan di Kabupaten Grobogan)
}

\author{
Wasitowati \\ Binti Khoiriyah
}

Fakultas Ekonomi Universitas Islam Sultan Agung Semarang

Diterima: April 2018. Disetujui: Juli 2018. Dipublikasikan: Oktober 2018

\begin{abstract}
This research is based on the gap phenomenon that occurs, where the number of PNS performance decreases such as lack of discipline in carrying out tasks, and this is related to a lack of leadership supervision, lack of understanding of employees to work is more oriented to responsibility and worship, if it is implanted it will motivation arises in employees to work properly and correctly.

The population in this study were civil servants who worked in the sub-district office in Grobogan district. The samples taken were 75 respondents using proportional sampling techniques.

The results of this study indicate that leadership leadership, work discipline, work orientation have a positive effect on achievement motivation and employee performance. Achievement motivation is not an intervening variable between the influence of leadership in consideration of employee performance, work discipline with employee performance, work orientation and employee performance. So that without the achievement motivation can still improve performance by improving the supervision of leaders to subordinates, providing examples of discipline so that subordinates will carry out discipline by themselves.
\end{abstract}

Keywords: Leadership Consideration, Work Discipline, Work Orientation, Achievement Motivation, Performance.

\begin{abstract}
ABSTRAK
Penelitian ini berdasarkan fenomena gap yang terjadi, dimana banyaknya kinerja PNS mengalami penurunan seperti kurang adanya kedisiplinan dalam melaksanakan tugas, dan hal tersebut berhubungan dengan kurangnya pengawasan pemimpin, kurangnya pemahaman kepada para karyawan untuk bekerja lebih berorientasi pada tanggungjawab dan ibadah, jika itu ditanamkan maka akan muncul motivasi dalam diri karyawan untuk bekerja dengan baik dan benar.

Populasi dalam penelitian ini adalah PNS yang bekerja dikantor kecamatan di kabupaten Grobogan. Sampel yang diambil sebanyak 75 Responden dengan menggunakan teknik proportional sampling.

Hasil penelitian ini menunjukan bahwa Kepemimpinan konsiderasi, Disiplin kerja, Orientasi kerja berpengaruh positif terhadap motivasi berprestasi dan kinerja pegawai. Motivasi berprestasi bukan merupakan variabel intervening di antara pengaruh kepemimpinan konsiderasi dengan kinerja pegawai, disiplin kerja dengan kinerja pegawai, orientasi kerja dengan kinerja pegawai. Sehingga tanpa adanya motivasi berprestasi tetap bisa meningkatkan kinerja dengan memperbaiki pengawasan pemimpin terhadap bawahannya, memberikan contoh kedisiplinan sehingga bawahan pun akan melaksanakan kedisiplinan dengan sendirinya.
\end{abstract}

Kata Kunci : Kepemimpinan Konsiderasi, Disiplin Kerja, Orientasi kerja, Motivasi berprestasi, Kinerja. 


\section{PENDAHULUAN}

Dalam era globalisasi dan seiring dengan kemajuan zaman, sebagai organisasi yang maju dituntut mampu untuk menyesuaikan diri serta terus melakukan perubahan perubahan yang terjadi. Setiap organisasi pada umumnya mengharapkan para pegawainya mampu melaksanakan tugasnya dengan efektif, efisien, produktif dan profesional. Semua ini bertujuan agar organisasi memiliki sumber daya manusia yang berkualitas dan sekaligus memiliki daya saing yang tinggi.

Kecamatan dilihat dari sistem pemerintahan Indonesia merupakan ujung tombak dari pemerintahan daerah yang langsung berhadapan dengan masyarakat luas. Citra birokrasi pemerintahan secara keseluruhan akan banyak ditentukan oleh kinerja organisasi tersebut. Kecamatan sebagai instansi pelayanan publik dituntut untuk memperbaiki dan senantiasa melakukan reformasi serta mengantisipasi perkembangan masyarakat yang terjadi. Dalam rangka meningkatkan citra, kerja dan kinerja instansi pemerintah menuju kearah profesionalisme dan menunjang terciptanya pemerintahan yang baik, perlu adanya penyatuan arah dan pandangan bagi segenap jajaran pegawai Pemerintah yang dapat dipergunakan sebagai pedoman atau acuan dalam melaksanakan tugas baik manajerial maupun operasional diseluruh bidang tugas dan unit organisasi Instansi Pemerintah secara terpadu.

Menpan-RB, awal tahun 2016 mengatakan bahwa kinerja PNS mengalami penurunan dalam kinerja mengurus perizinan, dimana banyak laporan yang menyatakan bahwa dalam perizinan masih cenderung lambat dalam proses pengurusan (Fokusjabar, 01 Januari 2016). Selain itu menurut Asisten Umum Setda Kabupaten Bandung Barat, pada beberapa daerah kinerja PNS di lingkungan Pemkab Bandung Barat, Jawa Barat menurun saat bulan puasa hal itu bisa terlihat saat pelaksanaan apel pagi dimana hanya sekitar 30 persennya saja yang hadir. Alasan berpuasa yang digunakan untuk menutupi ketidak hadiran padahal seharusnya PNS lebih termotivasi untuk lebih giat bekerja dengan niatan ibadah. (Media Nusantara, 16Juni 2016). Berdasarkan indeks membangun aparatur negara, Indonesia memiliki nilai 46, dari skala 0 sampai 100. Posisi itu di bawah Singapura, 
Malaysia, Filipina, dan Vietnam. Menpan-RB Sofian menuturkan rendahnya mutu ASN menjadi perhatian khusus karena memengaruhi kinerja dan pelayanan kepada publik dan disebutkan juga bahwa hal tersebut terjadi karena PNS dalam bekerja belum sesuai standart, terutama dalam hal cuti yang sering melebihi batas. Bupati Jalan Dorak Selatpanjang H.Edy menemukan banyak kinerja PNS yang dianggap lambat. Oleh sebab itu Bupati H.Edy mengingatkan kepada seluruh PNS untuk bekerja bukan semata-mata karena uang tapi harus berorientasi pada pelayanan publik. Beliau tidak ingin para PNS dalam menjalankan pekerjaan semakin hari semakin memprihatinkan. Akibatnya, pelayanan terhadap masyarakat sebagai salah satu tugas pokoknya tidak berfungsi dengan baik (RiauGreen.Com : 24 Agustus 2015)

Penelitian Siska Anggraeni Firdaus terdapat pengaruh antara Kepemimpinan konsiderasi terhadap motivasi berprestasi. Penelitian Yoti Gama Hita menunjukkan disiplin kerja berpengaruh signifikan terhadap motivasi berprestasi. Penelitian Agus Dwi Atmoko (2012) menunjukan terdapat hubungan yang signifikan antara orientasi kerja terhadap motivasi berprestasi. Ritawati (2013) menunjukkan adanya hubungan positif antara kepemimpinan konsiderasi terhadap kinerja. Akan tetapi penelitian Siska Anggraeni Firdaus menunjukan tidak ada pengaruh antara Gaya Kepemimpinan Konsiderasi terhadap Kinerja. Penelitian Raymundus I Wayan Ray (2015) menyatakan bahwa disiplin kerja berpengaruh terhadap kinerja PNS begitu juga budaya organisasi berpengaruh terhadap kinerja, akan tetapi penelitian Utari (2015) menunjukan disiplin berpengaruh tidak signifikan terhadap kinerja. Penelitian Wiwik Sudarmayanti (2015) menunjukan bahwa orientasi kerja berpengaruh terhadap kinerja pegawai kantor camat Loa Kulu kabupaten Kutai Kartanegara. Selanjutnya penelitian Hindria Hestisani menyatakan ada pengaruh positif dan signifikan motivasi berprestasi terhadap kinerja, akan tetapi penelitian guritno dan waridin (2005) menyatakan motivasi berprestasi berpengaruh negatif dan tidak signifikan terhadap kinerja.

Berdasarkan fenomena dan penelitian terdahulu, peneliti menemukan adanya kedisplinan PNS yang kurang dalam bekerja juga orientasi kerja dalam lingkup pekerjaan dikantor kecamatan yang terlanjur buruk dan menjadi kebiasaan turun temurun juga kurang adanya pengawasan dari pimpinan yang bisa 
mengakibatkan kinerja menjadi tidak sesuai aturan yang ada, dan ini jelas bertentangan dengan UUD Nomor 5 Tahun 2014 tentang aparatur sipil Negara pasal 5 yakni melaksanakan tugasnya dengan cermat dan disiplin melayani dengan sikap hormat, sopan, dan tanpa tekanan karena pada kenyataannya disiplin dalam bekerja masih kurang juga motivasi untuk bekerja yang sudah menjadi budaya dan terjadi di hampir semua PNS di kantor kecamatan sehingga untuk bisa terjadi perubahan harus ada pengawasan dari pimpinan kantor yakni pak camat dengan kepemimpinan yang lebih baik lagi dengan menggunakan pendekatan untuk memotivasi kinerja sehingga ada semangat untuk bekerja dan meningkatkan kedisiplinan sehingga kinerja PNS bisa lebih baik lagi.

\section{KAJIAN PUSTAKA DAN PERUMUSAN HIPOTESIS}

\section{Kepemimpinan Konsiderasi dan Motivasi Berprestasi}

Seorang pemimpin tidak hanya mengarahkan bawahannya saja akan tetapi juga harus bisa memberikan semangat dengan melakukan pendekatan-pendekatan sehingga akan tahu masalah apasaja yang dihadapi oleh bawahannya, dan dari situ akan muncul motivasi pada diri karyawan karena merasa mendapat perhatian dari pimpinan dan merasa dihargai. Gaya Kepemimpinan Konsiderasi menurut Thoha (2001) adalah perilaku dari seorang pemimpin dengan sikap saling percaya, mengahargai, rasa setiakawan, pemberian penghargaan atas dukungan bawahan serta komunikasi yang efektif dengan bawahan. Dimana menurut penelitian Siska Anggraeni Firdaus terdapat pengaruh antara Gaya Kepemimpinan Konsiderasi terhadap motivasi berprestasi.

Dari pendapat tersebut dapat dilihat bahwa sikap seorang pemimpin dalam hal ini adalah pak camat yang bisa memahami setiap karyawannya dan juga kebutuhan karyawannya akan memberikan motivasi tersendiri bagi karyawan karena merasa nyaman dalam bekerja dengan adanya perilaku baik dari seorang pemimpin. Sehingga ditarik kesimpulan bahwa terdapat pengaruh yang signifikan antara Kepemimpinan Konsiderasi terhadap Motivasi Berprestasi.

\section{H1: Kepemimpinan Konsiderasi berpengaruh positif dan signifikan terhadap Motivasi Berpresasi.}




\section{Disiplin Kerja dan Motivasi Berprestasi}

Fathoni (2006:126) kedisiplian adalah kesadaran dan kesediaan seseorang menaati semua peraturan perusahaan dan norma-norma sosial yang berlaku. Kedisiplinan harus ditegakkan dalam suatu organisasi perusahaan, karena tanpa dukungan disiplin karyawan yang baik, maka sulit perusahaan untuk mewujudkan tujuannya. Jadi, kedisiplinan adalah kunci keberhasilan suatu motivasi karyawan untuk mencapai tujuan. Mangkunegara (2000: 103) mengatakan "motivasi berprestasi dapat diartikan sebagai suatu dorongan dalam diri seseorang untuk melakukan atau mengerjakan suatu kegiatan atau tugas dengan sebaik-baiknya agar mencapai prestasi dengan predikat terpuji. Penelitian Yoti Gama Hita menunjukan Disiplin kerja berpengaruh signifikan terhadap motivasi karyawan. Hubungan antara disiplin kerja dan motivasi di tingkat perusahaan dapat memacu semangat kerja, dan salah satu yang tidak kalah pentingnya dalam mempengaruhi kemajuan dan keberhasilan sebuah organisasi.

Dari pendapat dan penelitian diatas dapat dilihat bahwa disiplin yang diakukan tanpa paksaan akan memotivasi diri dalam bekerja, sehingga dengan kedisiplinan dalam bekerja dengan memanfaatkan waktu yang sebaik-baiknya, pekerjaan akan selesai dengan baik sehingga memunculkan rasa puas dan semangat kerja. Dapat ditarik kesimpulan bahwa ada hubungan yang positif antara disiplin kerja terhadap motivasi

\section{H2: Disiplin Kerja berpengaruh positif dan signifikan terhadap Motivasi Berprestasi}

\section{Orientasi Kerja dan Motivasi Berprestasi}

Orientasi Kerja menurut Ingham (1970): "the concept formed the basis for the harmonious view of industrial relations in the small firm as orientation to work was said to cause" individual self-selection to the small firm sector. Yang kurang lebih memiliki arti: sikap dan tingkah laku pegawai, merupakan suatu konsep yang dapat menciptakan harmoni dalam bekerja dan sehingga dapat menyebabkan peningkatan kinerja pegawai secara individu dalam sebuah organisasi. Penelitian 
Agus Dwi Atmoko (2012) menjelaskan bahwa Orientasi Kerja berpengaruh terhadap Motivasi pegawai. Dalam penelitian tersebut dijelaskan bahwa.

Dari pendapat tersebut dapat ditarik kesimpulan bahwa terdapat pengaruh yang signifikan antara Budaya Organisasi terhadap Motivasi Berprestasi.

\section{H3: Orientasi Kerja berpengaruh positif dan signifikan terhadap Motivasi Berprestasi.}

\section{Kepemimpinan Konsiderasi dan Kinerja}

Kepemimpinan adalah proses mempengaruhi, menggerakkan, dan mengarahkan suatu tindakan pada diri seseorang dengan tujuan supaya bawahan bisa bekerja dan mengasilkan kinerja yang baik, bagaimana seorang pemimpin memimpin bawahannya akan terlihat dari hasil kinerja bawahannya tersebut. Pasolong (2008:81) menjelaskan kembali Konsiderasi adalah tingkat sejauh mana seorang pemimpin bertindak dengan cara ramah dan mendukung, memperlihatkan perhatian terhadap bawahan dan memperhatikan kesejahteraan mereka. Ritawati (2013) menunjukkan adanya hubungan positif antara kepemimpinan Konsiderasi terhadap kinerja.

Pemimpin harus bisa menentukan kemana arah perusahaan dan bagaimana karyawan bekerja, karna pemimpinlah yang akan dijadikan panutan. Sehingga bagaimana seseorang memimpin perusahaan akan terlihat dari hasil kinerja karyawan dan keberhasilan perusahaannya. Dari penelitian dapat dilihat bahwa terdapat pengaruh yang signifikan antara kepemimpinan terhadap kinerja.

\section{H4: Kepemimpinan Konsiderasi berpengaruh positif dan signifikan terhadap Kinerja.}

\section{Disiplin Kerja dan Kinerja}

Mempunyai kedisiplinan kerja dapat berdampak pada kehidupan pribadi karyawan yang berpengaruh pada organisasi. Untuk itu organisasi perlu mengawasi setiap tindakan dan perilaku yang dilakukan karyawan saat bekerja. Jika ada tindakan penyelewengan yang dilakukan karyawan maka harus ditindak tegas 
dengan peringatan lalu hukuman karena jika dibiarkan akan berdampak buruk bagi kinerja. Kedisiplinan yang terbentuk dengan baik dalam bekerja akan menghasilkan kinerja yang optimal karena memanfaatkan waktu dan tanggung jawab sebaik-baiknya. Penelitian Raymundus I Wayan Ray menunjukan terdapat pengaruh yang signifikan antara disiplin kerja terhadap kinerja PNS.

Disiplin dalam bekerja akan berdampak pada kinerja, karena disiplin akan memanfaatkan waktu yang ada sebaik mungkin sehingga besar kemungkinan pekerjaan dan tanggung jawab yang diterima karyawan akan terselesaikan dengan baik dengan berpedoman pada disiplin waktu. Dapat ditarik kesimpulan bahwa disiplin kerja berpengaruh positif terhadap kinerja.

\section{H5: Disiplin Kerja berpengaruh positif dan signifikan terhadap Kinerja}

\section{Orientasi Kerja dan Kinerja}

Orientasi haruslah bermula dengan jenis informasi yang relevan dan segera untuk dilanjutkan dengan kebijakan-kebijakan yang lebih umum tentang organisasi. Orientasi haruslah berlangsung dalam kecepatan yang membuat karyawan baru tetap merasa nyaman. Bagian paling signifikan adalah sisi manusianya, memberikan pengetahuan kepada karyawan baru tentang seperti apa para penyelia dan rekan kerjanya, berapa lama waktu yang dibutuhkan untuk mencapai standar kerja yang efektif, dan mendorong mereka mencari bantuan dan saran ketika dibutuhkan. Dalam penelitian Wiwik Sudarmayanti (2015) menunjukan bahwa terdapat pengaruh yang kuat antara Orientasi Kerja terhadap Kinerja pada kantor Camat Loa Kulu Kabupaten Kutai Kartanegara.

Dari pendapat tersebut dapat disimpulkan bahwa melalui Orienasi dapat terjalin komunikasi dengan orang lain melalui bahasa yang telah dipelajari dan digunakan bersama-sama. Melalui Orientasi pula, akan sangat memungkinkan bagi seseorang untuk mengantisipasi bagaimana reaksi orang-orang disekitarnya terhadap perilaku yang bersangkutan. Sehingga Orientasi Kerja yang baik dan menciptakan kenyamanan akan berpengaruh dalam kinerja yang nyaman dan baik 
juga. Dari pendapat tersebut dapat ditarik kesimpulan bahwa terdapat pengaruh yang signifikan antara Orientasi Kerja terhadap kinerja.

\section{H6: Orientasi Kerja berpengaruh positif dan signifikan terhadap Kinerja.}

\section{Motivasi Berprestasi dan Kinerja}

Kesuksesan organisasi dapat tercapai apabila didukung sumber daya manusia yang berkualitas dengan motivasi yang tinggi. Pegawai akan merasa senang atau puas apabila keinginannya terpenuhi. Motivasi kerja seorang pegawai merupakan penggerak bagi pegawai agar berusaha mencapai tujuan organisasi secara optimal. penelitian Hindria Hestisani (2007) menyatakan ada pengaruh positif dan signifikan motivasi berprestasi terhadap kinerja. Maka kontribusi motivasi Berprestasi terhadap kinerja yaitu apabila motivasi ditingkatkan maka akan berpengaruh terhadap kinerja yang juga akan mengalami peningkatan.

Motivasi merupakan salah satu faktor kunci untuk bekerja dan mencapai kinerja yang tinggi. Kegiatan memotivasi berkaitan dengan sejauhmana komitmen seseorang terhadap pekerjaannya dalam rangka mencapai tujuan perusahaan. Jika motivasi rendah maka semangat dalam bekerja akan mnenurun sehingga akan menghasilkan kinerja yang kurang baik. Dari pendapat tersebut dapat ditarik kesimpulan bahwa ada pengaruh yang signifikan antara Motivasi terhadap Kinerja.

\section{H7: Motivasi Berprestasi berpengaruh positif dan signifikan terhadap Kinerja.}




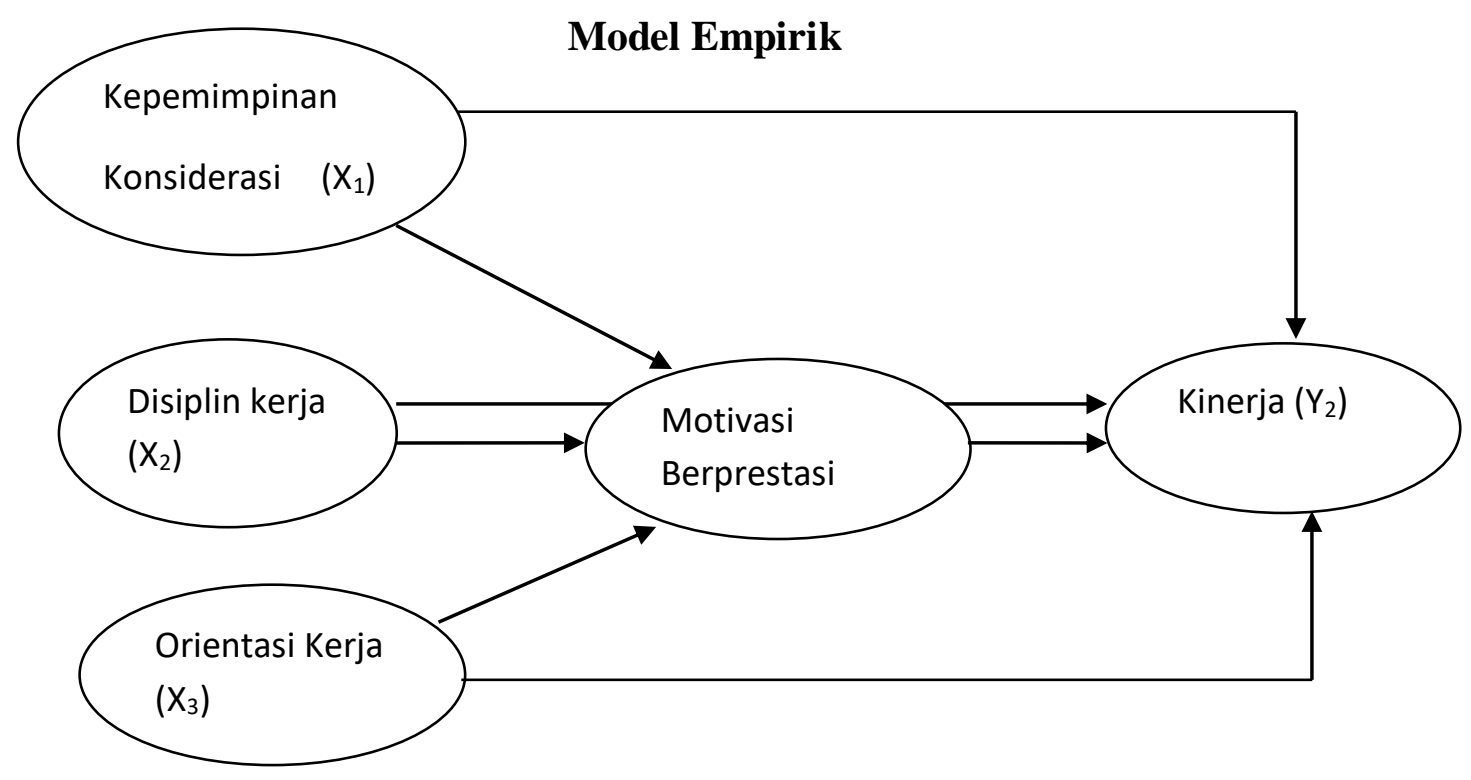

\section{METODE PENELITIAN}

Jenis penelitian yang digunakan untuk penelitian ini adalah penelitian penjelasan (explanatory research). Penelitian ini akan membuktikan hubungan antara variabel bebas (independent variable) yaitu kepemimpinan Konsiderasi, disiplin kerja dan Orientasi Kerja terhadap variabel terikat (dependent variable) yaitu kinerja dengan menggunakan variabel intervening (intervening variable) Motivasi berprestasi. Variabel intervening yakni type variabel yang mempengaruhi hubungan antara variabel dependen dengan variabel independen, serta antara dua variabel atau lebih memiliki hubungan atau tidak, dan seberapa besar serta bagaimana arah hubungan tersebut. (yasa, 2006:26)

\section{Populasi dan Sampel}

Kabupaten Grobogan mempunyai 19 Kecamatan, dengan jumlah PNS keseluruhan yang bekerja dikantor kecamatan sebanyak 323 PNS.

Sampel yang diambil sebanyak 75 Responden dengan menggunakan teknik proportional sampling yaitu pengambilan sampel yang memperhatikan pertimbangan unsur-unsur atau kategori dalam populasi penelitian 
Tabel 1

Sampel Penelitian

\begin{tabular}{|l|l|l|l|}
\hline No & Kecamatan & Populasi & Sampel \\
\hline 1 & Gabus & 16 & 10 \\
\hline 2 & Kradenan & 16 & 10 \\
\hline 3 & Pulokulon & 14 & 9 \\
\hline 4 & Wirosari & 28 & 14 \\
\hline 5 & Ngaringan & 17 & 11 \\
\hline 6 & Godong & 16 & 10 \\
\hline 7 & Penawangan & 17 & 11 \\
\hline & Total & 128 & 75 \\
\hline
\end{tabular}

\section{Teknik analisis data}

Uji regresi linier berganda

Analisi regresi linier berganda adalah analisis yang tujuannya untuk mengetahui apakah ada hubungan antara dua atau lebih variabel bebas dengan variabel terikat dan apakah positif atau negative. Atau untuk mengetahui seberapa besar pengaruh variabel dependen dengan variabel independen dan apakah positif atau negatif

Rumus :

$$
\begin{aligned}
& Y_{1}=a+b_{1} X_{1}+b_{2} X_{2}+b_{3} X_{3} \\
& Y_{2}=a+b_{1} X_{1}+b_{2} X_{2}+b_{3} X_{3}+b_{4} Y_{1}+e_{1}
\end{aligned}
$$

Dimana :

X1 : Kepemimpinan Konsiderasi

$\mathrm{X} 2$ : Disiplin Kerja

$\mathrm{X} 3$ : Orientasi Kerja

Y1 : Motivasi Berprestasi

Y2 : Kinerja

$b_{1}, b_{2}, b_{3}, b_{4}$ : Koefisien regresi variable bebas

$\mathrm{e}_{1}$ : eror term (tingkat kesalahan)

a : Konstanta 


\section{HASIL DAN PEMBAHASAN}

\section{Path Analisis}

Untuk penelitian ini data yang terkumpul diolah dengan menggunakan Path Analisis (analisis jalur). Dalam penelitian ini teknik analisis jalur path dilakukan dengan menggunakan analisis regresi linier berganda sebagai berikut:

Tabel 2

Hasil Analisis Jalur

\begin{tabular}{|c|c|c|c|c|c|c|c|c|c|}
\hline Regresi & $\begin{array}{l}\text { Variabel } \\
\text { Endogen }\end{array}$ & $\begin{array}{l}\text { Variabel } \\
\text { Eksogen }\end{array}$ & $\begin{array}{l}\text { Adjusted } \\
\text { R Square }\end{array}$ & $\mathbf{E}$ & $\begin{array}{l}\text { Koef } \\
\text { Jalur }\end{array}$ & $\mathbf{T}$ & $\mathbf{P}$ & $\begin{array}{l}\text { Efek } \\
\text { Lsng }\end{array}$ & $\begin{array}{c}\text { Efek } \\
\text { Tdk } \\
\text { lsg }\end{array}$ \\
\hline 1 & Y1 & $\begin{array}{l}\text { X1 } \\
\text { X2 } \\
\text { X3 }\end{array}$ & 0,553 & 3,125 & $\begin{array}{l}0,264 \\
0,569 \\
0,277\end{array}$ & $\begin{array}{l}2,289 \\
4,827 \\
3,412\end{array}$ & $\begin{array}{l}0,025 \\
0,000 \\
0,001\end{array}$ & $\begin{array}{l}0,264 \\
0,569 \\
0,277\end{array}$ & $\begin{array}{l}- \\
- \\
-\end{array}$ \\
\hline 2 & $\mathrm{Y} 2$ & $\begin{array}{l}\mathrm{X} 1 \\
\mathrm{X} 2 \\
\mathrm{X} 3 \\
\mathrm{Y} 1\end{array}$ & 0,759 & 1,198 & $\begin{array}{l}0,370 \\
0,446 \\
0,175 \\
0,183\end{array}$ & $\begin{array}{l}4,219 \\
4,473 \\
2,723 \\
2,095\end{array}$ & $\begin{array}{l}0,000 \\
0,000 \\
0,008 \\
0,040\end{array}$ & $\begin{array}{l}0,370 \\
0,446 \\
0,175 \\
0,183\end{array}$ & $\begin{array}{c}0,048 \\
0,104 \\
0,051 \\
-\end{array}$ \\
\hline
\end{tabular}

Berdasarkan tabel di atas, dapat dijelaskan persamaan regresi sebagai berikut :
a. $\mathrm{Y} 1=0,264 \mathrm{X} 1+0,569 \mathrm{X} 2+0,277 \mathrm{X} 3+\mathrm{e} 1$
b. $\mathrm{Y} 2=0,370 \mathrm{X}+0,446 \mathrm{X} 2+0,175 \mathrm{X} 3+0,183 \mathrm{Y} 1+\mathrm{e} 2$

Hasil persamaan regresi di atas, dapat di interprestasikan sebagai berikut :

Persamaan regresi $1: \mathrm{Y} 1=0,264 \mathrm{X} 1+0,569 \mathrm{X} 2+0,277 \mathrm{X} 3+\mathrm{e} 1$

a. Nilai koefisien regresi variabel kepemimpinan konsiderasi, sebesar 0,264, bernilai positif, dapat diartikan bahwa apabila kepemimpinan konsiderasi semakin meningkat, maka motivasi berprestasi semakin meningkat. 
b. Nilai koefisien regresi variabel disiplin kerja, sebesar 0,5694, bernilai positif, dapat diartikan bahwa apabila disiplin kerja semakin meningkat, maka motivasi berprestasi semakin meningkat.

c. Nilai koefisien regresi variabel orientasi kerja, sebesar 0,277 , bernilai positif, dapat diartikan bahwa apabila orientasi kerja semakin meningkat, maka motivasi berprestasi semakin meningkat.

Persamaan regresi 2: Y2 $=0,370 \mathrm{X}+0,446 \mathrm{X} 2+0,175 \mathrm{X} 3+0,183 \mathrm{Y} 1+\mathrm{e} 2$

a. Nilai koefisien regresi kepemimpinan konsiderasi, sebesar 0,370, bernilai positif, dapat diartikan bahwa apabila kepemimpinan konsiderasi semakin meningkat, maka kinerja pegawai semakin meningkat.

b. Nilai koefisien regresi disiplin kerja, sebesar 0,446 , bernilai positif, dapat diartikan bahwa apabila disiplin kerja semakin meningkat, maka kinerja pegawai semakin meningkat.

c. Nilai koefisien regresi orientasi kerja, sebesar 0,175 , bernilai positif, dapat diartikan bahwa apabila orientasi kerja semakin meningkat, maka kinerja pegawai semakin meningkat.

d. Nilai koefisien regresi motivasi berprestasi, sebesar 0,183 , bernilai positif, dapat diartikan bahwa apabila motivasi berprestasi semakin meningkat, maka kinerja pegawai semakin meningkat

\section{Pengaruh Kepemimpinan Konsiderasi Terhadap Motivasi Berprestasi}

Dari hasil perhitungan diperoleh nilai $t$ hitung adalah 2,289 dan dengan menggunakan level significance (taraf signifikan) sebesar 5 persen diperoleh t tabel sebesar 1,666 yang berarti bahwa nilai thitung lebih besar daripada nilai t tabel yaitu $2,289>1,666$.

Signifikasi t kurang dari 5 persen $(0,025)$, menandakan bahwa kepemimpinan konsiderasi mempunyai pengaruh yang signifikan terhadap motivasi berprestasi. Dengan demikian dapat disimpulkan bahwa Ho ditolak dan Ha diterima, sehingga hipotesis yang menyatakan dugaan adanya pengaruh kepemimpinan konsiderasi terhadap motivasi berprestasi diterima.

\section{Pengaruh Disiplin Kerja Terhadap Motivasi Berprestasi}

Dari hasil perhitungan diperoleh nilai t hitung adalah 4,827 dan dengan menggunakan level significance (taraf signifikan) sebesar 5 persen diperoleh $\mathrm{t}$ 
tabel sebesar 1,666 yang berarti bahwa nilai t hitung lebih besar daripada nilai t tabel yaitu $4,827>1,666$.

Signifikasi t kurang dari 5 persen $(0,000)$, menandakan bahwa disiplin kerja mempunyai pengaruh yang signifikan terhadap motivasi berprestasi. Dengan demikian dapat disimpulkan bahwa Ho ditolak dan Ha diterima, sehingga hipotesis yang menyatakan dugaan adanya pengaruh disiplin kerja terhadap motivasi berprestasi diterima.

\section{Pengaruh Orientasi Kerja Terhadap Motivasi Berprestasi}

Dari hasil perhitungan diperoleh nilai t hitung adalah 3,412 dan dengan menggunakan level significance (taraf signifikan) sebesar 5 persen diperoleh $\mathrm{t}$ tabel sebesar 1,666 yang berarti bahwa nilai t hitung lebih besar daripada nilai t tabel yaitu $3,412>1,666$.

Signifikasi t kurang dari 5 persen $(0,001)$, menandakan bahwa orientasi kerja mempunyai pengaruh yang signifikan terhadap motivasi berprestasi. Dengan demikian dapat disimpulkan bahwa Ho ditolak dan Ha diterima, sehingga hipótesis yang menyatakan dugaan adanya pengaruh orientasi kerja terhadap motivasi berprestasi diterima.

\section{Pengaruh Kepemimpinan Konsiderasi Terhadap Kinerja Pegawai}

Dari hasil perhitungan diperoleh nilai t hitung adalah 4,219 dan dengan menggunakan level significance (taraf signifikan) sebesar 5 persen diperoleh $\mathrm{t}$ tabel sebesar 1,666 yang berarti bahwa nilai $t$ hitung lebih besar daripada nilai t tabel yaitu $4,219>1,666$.

Signifikasi t kurang dari 5 persen $(0,000)$, menandakan bahwa kepemimpinan konsiderasi mempunyai pengaruh yang signifikan terhadap kinerja pegawai. Dengan demikian dapat disimpulkan bahwa Ho ditolak dan $\mathrm{Ha}$ diterima, sehingga hipotesis yang menyatakan dugaan adanya pengaruh kepemimpinan konsiderasi terhadap kinerja pegawai diterima.

\section{Pengaruh Disiplin Kerja Terhadap Kinerja Pegawai}

Dari hasil perhitungan diperoleh nilai t hitung adalah 4,473 dan dengan menggunakan level significance (taraf signifikan) sebesar 5 persen diperoleh $\mathrm{t}$ tabel sebesar 1,666 yang berarti bahwa nilai t hitung lebih besar daripada nilai t tabel yaitu $4,473>1,666$. 
Signifikasi t kurang dari 5 persen $(0,000)$, menandakan bahwa disiplin kerja mempunyai pengaruh yang signifikan terhadap kinerja pegawai. Dengan demikian dapat disimpulkan bahwa Ho ditolak dan Ha diterima, sehingga hipotesis yang menyatakan dugaan adanya pengaruh diisplin kerja terhadap kinerja pegawai diterima.

\section{Pengaruh Orientasi Kerja Terhadap Kinerja Pegawai}

Dari hasil perhitungan diperoleh nilai thitung adalah 2,723 dan dengan menggunakan level significance (taraf signifikan) sebesar 5 persen diperoleh $\mathrm{t}$ tabel sebesar 1,666 yang berarti bahwa nilai t hitung lebih besar daripada nilai t tabel yaitu $2,723>1,666$.

Signifikasi t kurang dari 5 persen $(0,008)$, menandakan bahwa orientasi kerja mempunyai pengaruh yang signifikan terhadap kinerja pegawai. Dengan demikian dapat disimpulkan bahwa Ho ditolak dan Ha diterima, sehingga hipotesis yang menyatakan dugaan adanya pengaruh orientasi kerja terhadap kinerja pegawai diterima.

\section{Pengaruh Kinerja Pegawai Terhadap Kinerja Pegawai}

Dari hasil perhitungan diperoleh nilai t hitung adalah 2,095 dan dengan menggunakan level significance (taraf signifikan) sebesar 5 persen diperoleh $\mathrm{t}$ tabel sebesar 1,666 yang berarti bahwa nilai t hitung lebih besar daripada nilai $t$ tabel yaitu 2,095 > 1,666.

Signifikasi t kurang dari 5 persen $(0,040)$, menandakan bahwa motivasi berprestasi mempunyai pengaruh yang signifikan terhadap kinerja pegawai. Dengan demikian dapat disimpulkan bahwa Ho ditolak dan Ha diterima, sehingga hipotesis yang menyatakan dugaan adanya pengaruh motivasi berprestasi terhadap kinerja pegawai diterima.

\section{Pengaruh Langsung dan Tidak Langsung}

\section{a. Pengaruh Kepemimpinan Konsiderasi terhadap Kinerja Pegawai Melalui Motivasi Berprestasi}

Hasil pengolahan data dengan path analisis diperoleh hasil sebagai berikut

Nilai pengaruh langsung kepemimpinan konsiderasi terhadap kinerja pegawai sebesar 0,370 lebih besar dibandingkan dengan pengaruh tidak 
langsung sebesar 0,048 yang berasal dari $(0,264 \times 0,183)$, dengan demikian dalam penelitian ini kepemimpinan konsiderasi berpengaruh langsung terhadap kinerja pegawai tidak melalui motivasi berprestasi.

\section{b. Pengaruh Disiplin Kerja terhadap Kinerja Pegawai Melalui Motivasi Berprestasi}

Nilai pengaruh langsung disiplin kerja terhadap kinerja pegawai sebesar 0,446 lebih besar dibandingkan dengan pengaruh tidak langsung sebesar 0,104 yang berasal dari $(0,569 \times 0,183)$, dengan demikian dalam penelitian ini disiplin kerja berpengaruh langsung terhadap kinerja pegawai tidak melalui motivasi berprestasi.

\section{c. Pengaruh Orientasi Kerja terhadap Kinerja Pegawai Melalui Motivasi Berprestasi}

Nilai pengaruh langsung orientasi kerja terhadap kinerja pegawai sebesar 0,175 lebih besar dibandingkan dengan pengaruh tidak langsung sebesar 0,051 yang berasal dari $(0,277 \times 0,183)$, dengan demikian dalam penelitian ini orientasi kerja berpengaruh langsung terhadap kinerja pegawai tidak melalui motivasi berprestasi.

\section{SIMPULAN}

Berdasarkan penelitian yang telah dilakukan, maka dapat dibuat simpulan sebagai berikut :

1. Kepemimpinan konsiderasi berpengaruh positif terhadap motivasi berprestasi dan kinerja pegawai, hal ini dapat diartikan bahwa apabila kepemimpinan konsiderasi yang di jelaskan oleh indikator sikap baik pimpinan terhadap pegawai, pimpinan menyediakan waktu untuk bawahan berkonsultasi, pimpinan mempunyai inisiatif yang tinggi, pimpinan selalu berkonsultasi dengan bawahan sebelum melaksanakan hal penting, pimpinan membuat peraturan-peraturan yang dapat mengendalikan keamanan dan kenyamanan pegawai, dan pimpinan memperlakukan bawahan sebagai sesama, semakin meningkat, maka motivasi berprestasi dan kinerja pegawai akan semakin meningkat.

2. Disiplin kerja berpengaruh positif terhadap motivasi berprestasi dan kinerja pegawai, hal ini dapat diartikan bahwa apabila disiplin kerja yang di jelaskan 
oleh indikator selalu datang dan pulang kerja tepat waktu, selalu berpakaian rapi di tempat kerja, menjaga dan mempergunakan alat kantor dengan hati-hati, bekerja sesuai aturan yang ada, dan selalu menyelesaikan pekerjaan yang diberikan oleh pimpinan, semakin meningkat, maka motivasi berprestasi dan kinerja pegawai akan semakin meningkat.

3. Orientasi kerja berpengaruh positif terhadap motivasi berprestasi dan kinerja, hal ini dapat diartikan bahwa apabila orientasi kerja yang di jelaskan oleh indikator lebih mengutamakan hasil kerja daripada prosesnya, dalam bekerja tidak ingin mengganggu dan memberikan dampak buruk bagi pegawai lain, dan lebih mengutamakan kegiatan organisasi daripada kegiatan individu semakin meningkat, maka motivasi berprestasi dan kinerja pegawai akan semakin meningkat.

4. Motivasi berprestasi berpengaruh positif terhadap kinerja pegawai, hal ini dapat diartikan bahwa apabila motivasi berprestasi yang di jelaskan oleh indikator tidak pernah menyalahkan orang lain dalam kegagalan kinerja, selalu siap mendengarkan kritikan orang lain tentang kinerja, tidak takut dengan segala risiko dalam bekerja, ingin diberikan kebebasan dalam berkarya, tidak pernah menunda pekerjaan, dan bangga dengan hasil kerja, maka kinerja pegawai semakin meningkat.

5. Motivasi berprestasi bukan merupakan variabel intervening di antara pengaruh kepemimpinan konsiderasi dengan kinerja pegawai, hal ini mengindikasikan kepimpinan dengan cara mendekati pegawai, bersikap ramah dan mendukung pegawai akan membuat kinerja pegawai akan semakin meningkat, sebab pimpinan berperan aktif dalam peningkatan kinerja, walaupun pegawai termotivasi atau tidak untuk berprestasi.

6. Motivasi berprestasi bukan merupakan variabel intervening di antara pengaruh disiplin kerja dengan kinerja pegawai, hal ini mengindikasikan disiplin kerja akan berdampak pada waktu lost time jadi berkurang dan pegawai memiliki waktu bekerja lebih lama, selain itu pegawai juga lebih taat terhadap peraturan kerja, sehingga menghasilkan kinerja pegawai yang tinggi, walaupun pegawai termotivasi atau tidak untuk berprestasi. 
7. Motivasi berprestasi bukan merupakan variabel intervening di antara pengaruh orientasi kerja dengan kinerja pegawai, hal ini mengindikasikan orientasi kerja yang tepat akan membuat pegawai bekerja dengan skala prioritas dan pegawai bisa mengesampingkan hal-hal yang tidak penting dalam bekerja, sehingga akan meningkatkan kinerja pegawai, walaupun pegawai termotivasi atau tidak untuk berprestasi.

\section{Saran}

Berdasarkan kesimpulan yang telah dikemukakan, maka diberikan beberapa saran yang diharapkan dapat meningkatkan kepuasan kerja dan kinerja pegawai. Adapun saran-saran yang diberikan adalah sebagai berikut :

1. Dalam variabel Orientasi kerja, lebih mengutamakan kegiatan organisasi daripada individu mendapatkan respon paling sedikit dari responden, sehingga pemimpin harus bisa meningkatkan kesadaran bawahannya untuk lebih mengutamakan kepentingan organisasi dengan memberikan pengarahan tentang pentingnya saling bekerja sama, karena mereka bekerja sebagai team bukan individual.

2. Dalam variabel motivasi berprestasi, kebiasaan menunda pekerjaan harus dihilangkan, dengan cara yakni pemimpin memberikan pengawasan lebih, dan memberikan penekanan waktu penyelesaian pekerjaan sehingga harus segera terselesaikan.

3. Dalam variabel disiplin kerja kebiasaan buruk mempergunakan alat kantor bukan untuk kepentingan kerja juga harus dihilangkan, karena jika terjadi kerusakan akan berpengaruh terhadap kinerja, dari hal disiplin kecil yakni menjaga alat kantor yang masih kurang bagaimana meningkatkan disiplin yang lainnya, sehingga perlu pengawasan.

\section{DAFTAR PUSTAKA}


Anggraini, Siska. Pengaruh Gaya kepemimpinan Consideration dan Initiating Structure terhadap Kinerja dengan Kepuasan Kerja sebagai Variabel Intervening. Jurnal aplikasi manajemen. Institut Teknologi Sepuluh November Surabaya.

Atmoko, Agus.2012. Pengaruh budaya organisasi, prndidikan dan pelatihan terhadap kinerja pegawai dengan motivasi sebagai intervening. Jurnal ekonomi. Vol 1 No 1. Universitas Politeknik.

Hamalik, Oemar. 2000. Manajemen pelatihan ketenagakerjaan. Bumi aksara, Jakarta.

Hestiana, Hindria. 2014. Pengaruh Motivasi Berprestasidan Disiplin Kerja terhadap Kinerja Pegawai pada Badan Kepegawaian Kabupaten Buleleng. Jurnal Bisma. Vol 2. Universitas Pendidikan Ganesha Singaraja.

Luthans, F. 2005. Organizational Behavior. New York: McGraw-hill..

Mathis, R.L. \& J.H. Jackson. 2006. Human Resource Management: Manajemen Sumber Daya Manusia. Terjemahan Dian Angelia. Jakarta: Salemba Empat.

Mangkunegara, Anwar Prabu . 2002. Manajemen Sumber Daya Manusia. Remaja Rosdakarya. Bandung

Nurlaila, 2010. Manajemen Sumber Daya Manusia I. Penerbit LepKhair.

Nurwati, 2012. Pengaruh kepemimpinan terhadap budaya organisasi, komitmen kerja, perilaku kerja, dan kinerja pegawai. Jurnal aplikasi manajemen Vol 10 No 1. Universitas Haluoleo. Kendari.

Pasolong, Harbani. 2008. Kepemimpinan Birokrasi. CV. Alfabeta. Bandung.Rivai, Veithzal. 2004. Manajemen Sumber Daya Manusia Untuk Perusahaan. PT RAJAGRAFINDA PERSADA. Jakarta.

Rivai, Veithzal, 2009. Kepemimpinan dan perilaku organisasi edisi ketiga, Jakarta, PT Rajagrafindo Persada.

Soedjono, 2005. Pengaruh budaya organisasi terhadap kinerja Organisasi dan Kepuasan Kerja karyawan pada Terminal penumpang Umum di Surabaya. Jurnal Manajemen dan Kewirausahaan. Vol 7, No. 1, Maret, hal. 23. Universitas Kristen Petra: Surabaya. 
Majalah Ilmiah Solusi

Vol. 16, No. 4 Oktober 2018

ISSN : 1412-5331

Soedjono, imam. 2002. Teknik memimpin Pegawai dan Pekerja.Jakarta:Aksara Baru 
Majalah Ilmiah Solusi

Vol. 16, No. 4 Oktober 2018

ISSN : 1412-5331 